\title{
Conformation traits of dairy cattle populations in selected Districts of Northwestern Amhara, Ethiopia
}

\author{
MISGANAW MAMMO ${ }^{1}$, KEFYALEW ALEMAYEHU ${ }^{2, \boldsymbol{v}}$, ASAMINEW TASSEW ${ }^{2}$ \\ ${ }^{1}$ Department of Animal Science, Debre Markos University, Bure Campus, Ethiopia \\ ${ }^{2}$ Department of Animal Production and Technology, College of Agriculture and Environmental Sciences, Bahir Dar University, Bahir Dar, Ethiopia. \\ "email:kefyale@gmail.com
}

Manuscript received: 10 August 2017. Revision accepted: 25 October 2017.

\begin{abstract}
Mammo M, Alemayehu K, Tassew A. 2017. Conformation traits of dairy cattle populations in selected Districts of Northwestern Amhara, Ethiopia. Biodiversitas 18: 1669-1679. The study was conducted in three selected districts of northwestern Amhara. The objective was to quantify the characteristics of conformation traits of dairy cattle populations at smallholder farmers' level. 279 cattle keepers were selected for measurement of conformation traits. About 105 indigenous cattle from each district and 42 crossbred female cattle were considered for measurement. SPSS (2007) was used to analyze qualitative data and SAS (2014) for quantitative data. The results revealed that the conformation trait measurements $(\mathrm{cm})$ of indigenous cattle had significant variation $(\mathrm{P}<$ $0.001)$ on neck length for dairy type $(54.07 \pm 4.80)$ and meat type $(51.96 \pm 4.05)$ traits. The width at the point of the shoulder was 7.72 $\pm 1.96,6.60 \pm 1.68$ and $5.35 \pm 1.61$ for meat type, dual type and for dairy type cattle, respectively. A male cattle had significant variation over female except neck length. All qualitative traits were laid intermediate levels (4-6 point) except crossbred which was $63.64 \%$. About $30 \%$ of dairy type cattle had high rear udder depth and $43.33 \%$ dairy type cattle had strong central ligament. Crossbred cattle had $42.1 \%$ sickled rear leg. In general, about $57.5 \%$ dairy type cattle and $95.2 \%$ crossbred cattle have very angular shape as $75 \%$ of meat type cattle lack angularity. From this research, it could be concluded that there were significant differences of conformation traits between dairy type and beef type cattle from the cattle population considered in the study for developing specialized dairy or beef breed types. As well as indigenous dairy type cattle are comparable to other known dairy cattle breeds like Kanan, Fogera and Barka. However, farmers did not exercise in developing product specific and specialized breeds with their corresponding production system than multipurpose. Thus, selection and appropriate planed breeding program is crucial for future dairy cattle genetic improvement to match genotype and environment and meet producers' production objectives. Hence, conformation traits can be a vital tool to make decisions on cattle selection and breed improvement.
\end{abstract}

Keywords: Cattle types, conformation traits, breed types, breed performance

\section{INTRODUCTION}

In order to ensure proper conservation and utilization of indigenous breeds, it is necessary to evaluate genetic variations that exist within and among breeds. A large proportion of indigenous livestock populations in the developing world have yet to be characterized or evaluated at phenotypic and genetic levels (Hanotte and Jianlin 2005). Most existing classification of livestock breeds in Africa is based on historical, anthropological and morphological evidence, which are most often not enough for the purpose of conservation (Mwacharo et al. 2006).

Ethiopia has one of the largest livestock inventories in Africa with a national herd estimated at 57.83 million cattle's consisted of local breeds $(98.59 \%$, crossbred $(1.22 \%)$, and exotic breed (0.19). The country has also 28.89 million sheep, 29.70 million goats and 10.37 million pack animals (CSA 2015/2016). Ethiopia is endowed with the highest cattle populations in Africa which serve as one of the most important sources of food and cash income. Cattle production system in Ethiopia is mainly smallholder substance farming, with animals having multipurpose use and as such, no specialized and systematic breeding is used (Tadesse et al. 2014).
Indigenous cattle populations were divided into three groups: dairy type, dual type and meat type due to great variability of conformation traits. Especially cattle have developed traits like long neck and sharp width at point of shoulder has characterized under dairy type and cattle develop wide shoulder, thick and short neck characterized under meet type.Variation of conformation traits among indigenous cattle population is great opportunity for selection and genetic improvement for the future. similarly Bahashwan (2014) reported that, morphometric traits measurements is conducted for characterize breeds of animals and can be an essential tool for the program selection and breed improvement. Because of low productivity, adapted indigenous breeds are subjected to crossbreeding with imported dairy cattle like Holstein and Jersey.Mistakes in breeding program have missed the opportunity to improve and preserve the indigenous breed. Similarly, Tesfa et al. (2016) reported that, Fogera cattle breed is well known for its milk production but, currently its productivity is declined because of different problems like genetic admixture with uncharacterized local breeds and inbreeding, shift of production system, absence of well-defined breeding programs, poor selection strategy and genetic gain. 
The role of conformation traits an indigenous dairy cattle improvement program is not well described Northwestern Amhara, West Gojjam administrative zone is one of administration zone which has high cattle population ( 471,816 cows of 1648 cross and 595,075 oxen) potential and suitable weather conditions for cattle production from Amhara regional state. Lack of proper characterization of conformation traits, identification, valuation, and maintenance of different traits of cattle and trait preference and identification of farmer were the main problems in the area. The quantification of conformation traits like udder related conformation traits had paramount importance in identifying dairy type traits. Since none of the conformation traits data for indigenous cattle types has previously been studied, in the present we analyzed conformation traits measurements to characterize this cattle types.Therefore, the objective of this paper was to undertake characterization of conformation traits for identifying and developing dairy type cattle from the indigenous cattle population.

\section{MATERIALS AND METHODS}

\section{Description of the study areas}

The research was done in three selected districts (Debecha, Quarit and Finote Selam) of West Gojjam administrative zones of western Amhara located at $300 \mathrm{~km}$ (Debecha), 427 km (Quarit), and 385 km (Finote Selam) from Addis Ababa (Figure 1, Table 1).

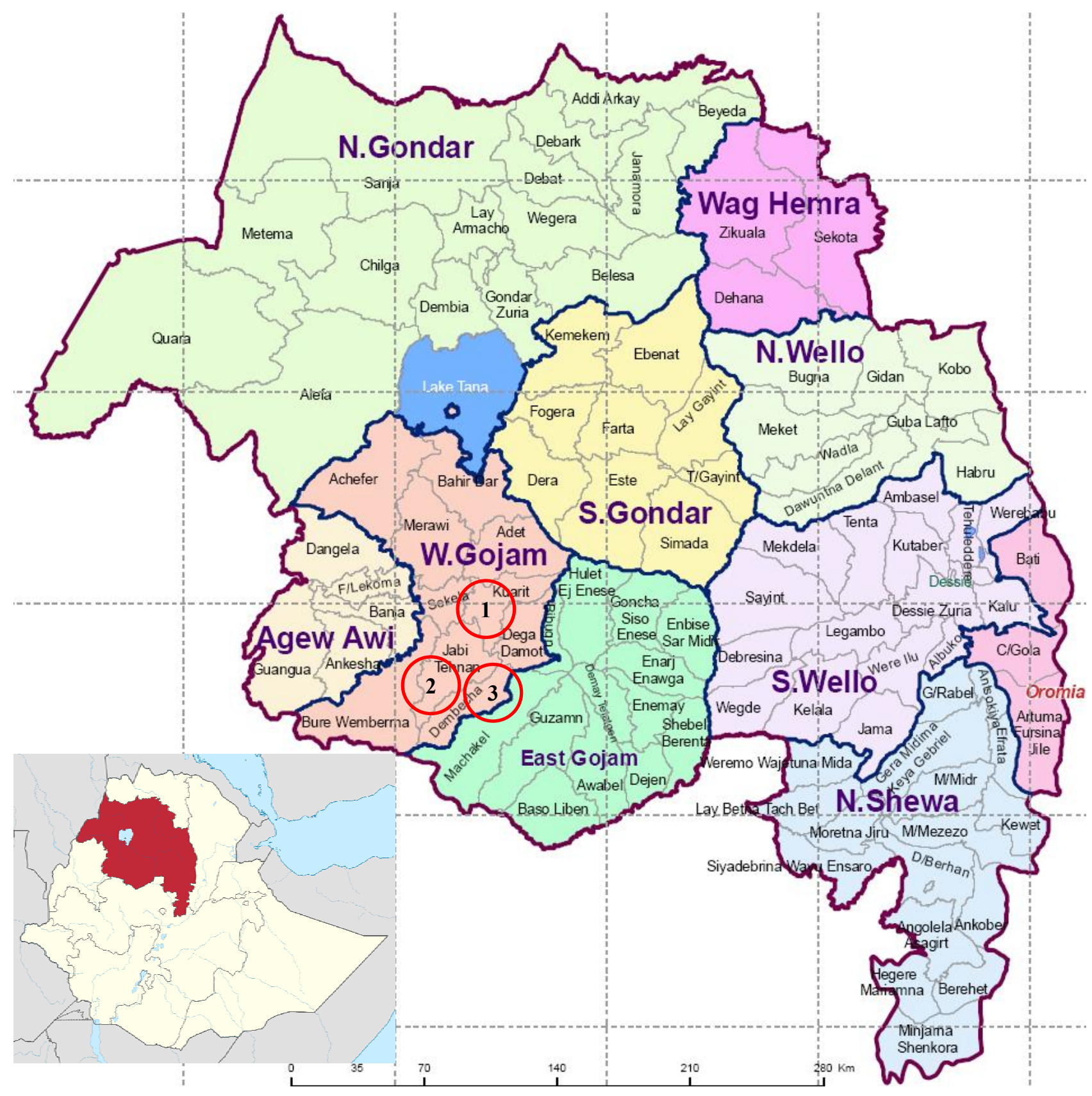

Figure 1. Map of the study areas in three selected districts of West Gojjam, Amhara, Ethiopia. Note: 1. Quarit, 2. Finote Selam, and 3. Debecha 
Table 1. Geographic coordinates of the sampling location and number of livestock populations in 2016

\begin{tabular}{lccccccc}
\hline \multicolumn{1}{c}{ District } & $\begin{array}{c}\text { Altitude } \\
\text { (a.s.l) }\end{array}$ & $\begin{array}{c}\text { Temp. } \\
\left({ }^{\circ} \mathbf{C}\right)\end{array}$ & $\begin{array}{c}\text { Annual rainfall } \\
(\mathbf{m m})\end{array}$ & \multicolumn{2}{c}{ Cattle populations (head) } & \multicolumn{2}{c}{ Other livestock's (head) } \\
Indigenous & Cross & Sheep & Goat \\
\hline Quarit & $1920-3000$ & $16-25$ & 1250 & 293,118 & - & 84,245 & 119,926 \\
Finote Selam & 1862 & $14-32$ & 1250 & 7821 & - & 2580 & 1403 \\
Debecha & 2080 & $18-24$ & 1006 & 133052 & 175 & 45763 & 12714 \\
\hline
\end{tabular}

Note: District Agricultural Offices, 2015

\section{Sampling technique and data collection procedures}

Before sampling, series of discussions were made with the Zonal and District livestock health and marketing agency experts in order to have information on the infrastructure, cattle and its distribution in the areas. The first stage involved selected three districts purposively based on cattle population. The district agricultural development offices and livestock development and health agencies were contacted for brief discussion on traditionally recognized indigenous cattle types. The distribution of households in the districts and selection of sample were done together with experts and development workers. A total of 279 cattle keepers were interviewed for the study (93 from each district). A multistage sampling technique was employed to gather the required information on conformation traits for dairy and meat type characterization.

Morphological measurements were taken using graduated measuring tape in full. Body measurements were made on adult cattle of both sexes, which were selected based on dentition technique. Because farmers often did not have birth records, age was estimated by examining each animal's teeth as suggested by Pace and Wakeman (2003), besides of asking cattle owners. Only animals with an eruption of the fourth pair of teeth, indicating maturity, were included in the study. All measurements were recorded after humanely restraining the randomly selected animals. Veerkamp et al. (2002), subjective visual assessment of animals by classifiers is undertaken for several different purposes in livestock.

The linear conformation traits were measured in centimeter $(\mathrm{cm})$ using graduated measuring stick and flexible tape. A separate form was prepared for each animal measured. Visual observations were made and morphological features were recorded based on cattle morphological characteristics descriptor list of FAO (2012), and International Committee for Animal Recording (ICAR 2015), breed descriptor list. Traits for both sexes had been calculated with Angularity (ANG (number of finger between last ribs and point given. Traits for both sexes had been calculated with Angularity (ANG (number of finger between last ribs and point given for angularity)), Rump angle (RA), Rear legs set (RLS) and 6 udder measurement traits Udder Depth (UD), Rear Udder Height (RUH), Central Ligament (CL), Rear Teat Placement (RTP), Front teat placement (view from behind) (FTP), Fore Udder Attachment) (FUA)) were female at milking stage. All above measurements were classified on a scale of 1 to 9. Traits on the shape and appearance of the animals were recorded in pre-coded format. Some photos were taken on matured animals for ease of comparison and description with other standard cattle types.

Before taken measurement, indigenous cattle were visually assessed by types (done by researcher). All measurements were recorded after humanely restraining the randomly selected animals. All measurements were carried out by the same person in order to avoid between individual variations; a separate form was prepared for each animal.

Body length (BL), Weather height (WH), Stature (ST), Width at point of shoulder (WAS), Navel flap length (NvF), Body depth (BD), scrotum length (SL), Perpetual sheath width (PSL), scrotum circumference (SC) and neck length were measured using a flexible centimeter while a heart girth meter was used. The definitions of conformation traits are indicated in Table 2.

According to emphasize of autochthonous traits indigenous cattle were classified in three groups: dairy type, dual type, meat type.

\section{Data management and analysis}

The data was collected from 357 cattle (315 indigenous,53 male and 262 female and 42 cross female) cattle. Indigenous cattle were grouped into three (123 dairy type, 111 dual types, and 81 meat types) cattle on the basis of variables and visual judgments of conformations traits. Categorizations were also done in cattle type, district, and sex. Before analysis, the data was encoded and filled in Microsoft Excel as per the categories. Data was analyzed according to the statistical package with the General Linear Model (GLM) procedure of SAS (SAS 9.1.3), in Duncan multiple range test and the qualitative phenotypic data and information from the questionnaire were analyzed using Statistical Package for Social Sciences SPSS (2007).

The quantitative and qualitative data were analyzed for both sexes separately to avoid confounding effect due to sex and each cattle type to see their variation. General Linear Model (GLM) procedure of SAS (9.1.3) was used for metric data to differentiate between location and cattle type (with cross, dairy, dual and meat type cattle) and correlation analysis.

Significant differences in means were separated using Duncan's Multiple Range Test. The model used for GLM analysis was:

$\mathrm{Yijkl}=\mu+\mathrm{Nj}+\mathrm{Sk}+\mathrm{Bl}+\mathrm{SKxBL}+\mathrm{Eijkl}$

Yijkl $=$ Observed value of the trait of interest

$\mu=$ over all mean

$\mathrm{Nj}=$ the effect of $\mathrm{j}^{\text {th }}$ sex (male and female) 
Table 2. Definitions of conformation traits

\begin{tabular}{|c|c|c|}
\hline Traits & & Specifications \\
\hline Body length & BL & The distance between point of shoulder and the pin bone \\
\hline Neck length & NL & Proximal end of cervical region to the distal end of the cranial region \\
\hline Heart girth & HG & Circumference of the body behind the base of the hump and just behind the front legs \\
\hline Height at withers & - & The vertical distance between ground and the point of wither \\
\hline Rump width & RW & Width between the two pins \\
\hline Perpetual sheath width & PSL & Widest part vertically from the base of the abdomen \\
\hline Teat length & - & From the base of the udder to the point of the teat \\
\hline Rump Angle & RA & pins high/low) is the degree of slope from hooks to pins when the cow is standing. \\
\hline Rear Legs Sets & RLS & $\begin{array}{l}\text { posty/sickle) is a measurement of the set of hock. A score of } 1 \text { indicates extremely posty legs and } \\
\text { a score of } 9 \text { indicates sickle hocked legs. }\end{array}$ \\
\hline Fore Udder Attachment & FUA & is an evaluation of the strength of attachment of the fore udder to the body wall. \\
\hline Rear Udder Height & RUH & $\begin{array}{l}\text { is measured as viewed from the rear, at the crease where the udder meets the leg, in relation to the } \\
\text { midpoint between the points of hock and pins. }\end{array}$ \\
\hline Central ligament & $\mathrm{CL}$ & $\begin{array}{l}\text { is a measure of the depth of cleft of the udder between the rear teats from the base of the rear teats } \\
\text { to the point where the halves of the udder come together. }\end{array}$ \\
\hline $\begin{array}{l}\text { Udder depth } \\
\text { (deep/shallow): }\end{array}$ & UD & is a measure of the depth of udder floor relative to the hock. \\
\hline $\begin{array}{l}\text { Front Teat Placement } \\
\text { (wide/close): }\end{array}$ & FTP & is a measurement of the placement of the front teat on the quarter \\
\hline
\end{tabular}

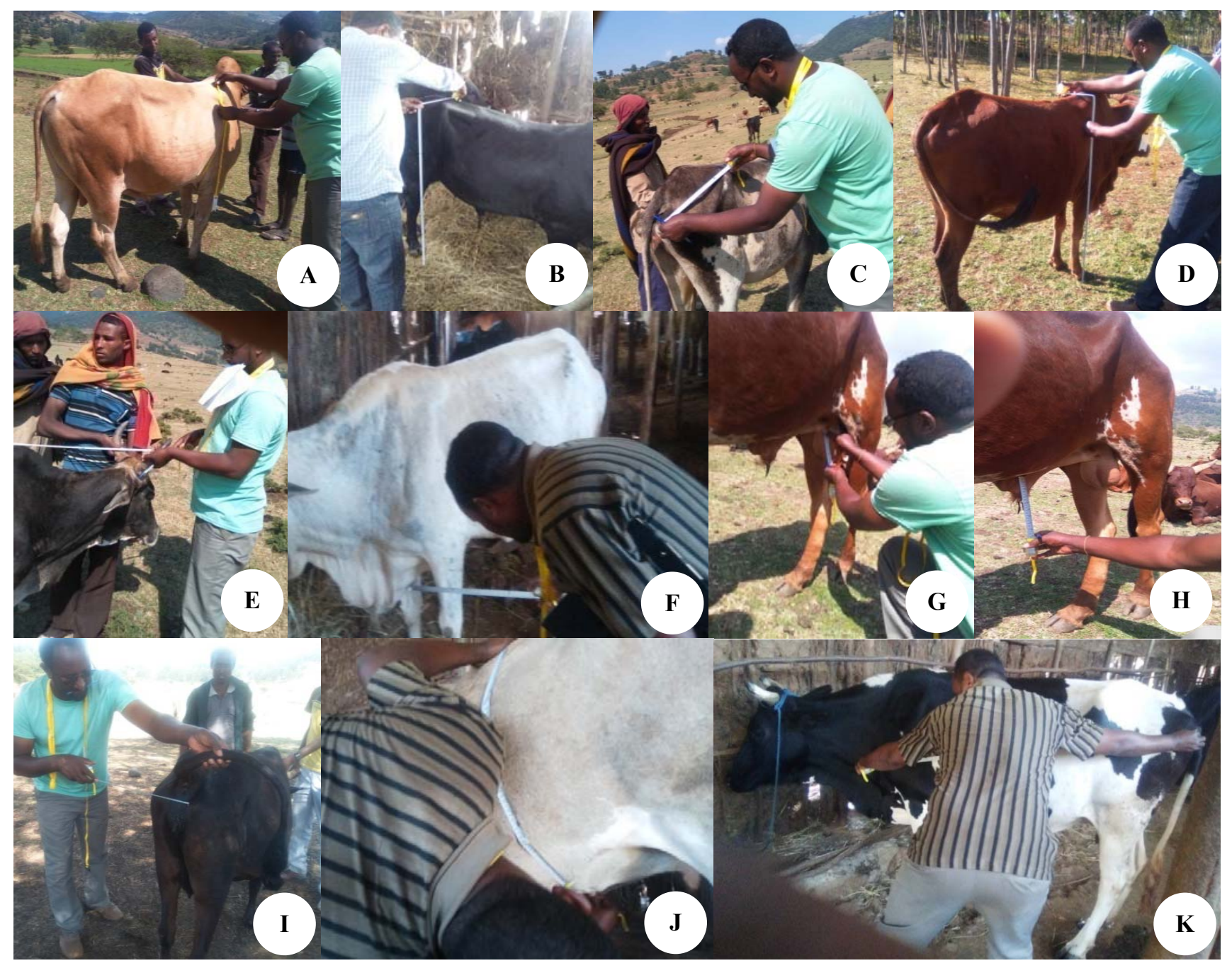

Figure 2. Morphological body measurements in the field. Note: $A=H G, B=R H, C=R L, D=W H, E=N L, F=C W, G=S L, H=P S L, I=$ $\mathrm{RW}, \mathrm{J}=\mathrm{BD}, \mathrm{K}=\mathrm{BL}$ 
$\mathrm{SK}=$ the effect of $\mathrm{k}^{\text {th }}$ agroecology /districts (Quarit, Finote Selam and Denbcha)

$\mathrm{BL}=$ then effect of $\mathrm{t}^{\text {th }}$ breed (dairy type, dual type, meat type and cross)

$\mathrm{SKXBL}=$ interaction effects of breed with agroecology

$\mathrm{Ejkl}=$ the random residual error

\section{RESULTS AND DISCUSSION}

\section{Conformation traits characterization}

In this research, the neck length (NL) of dairy type had significant variation $(\mathrm{P}<0.01)$ than meat type and dual purpose type cattle (Table 3 and Figure 3 ). Neck length of dairy type was higher than Kanan cattle $43.04 \pm 0.43$ (Aamir et al. 2010) since Kanana cattle is dairy cattle in Northern Sudan as reported by Rege (1999) and Bagit/ Barka cattle $47.14 \pm 0.09$ (Ftiwi 2015). The length and thin neck is an indicator of angularity a common conformation of ideal dairy type. The short and thick neck is an indicator of rectangularity a common conformation of meat type/beef cattle. Long, lean and blending smoothly into the shoulder, clean cut throat is an excellent dairy character (ICAR 2015). Dairy form is an important indicator of cow's ability to mobilize energy (fat reserves) to milk (Tsuruta 2005)
Dairy type cattle had significant variation $(\mathrm{P}<0.01)$ on $\mathrm{BD}$ than dual and meat types in female populations (Table 3 ). It was an indicator of the wide hind quarter and more angularity in dairy-type than others. Crossbred cattle had significant variation $(94.38 \pm 7.91, \mathrm{P}<0.001)$ than all the rest of indigenous cattle. The measurement of BL in Fogera cattle was similar to dairy types and dual type cattle in the study area but lower than meat type cattle. Fogera breed is considered as a high milk producer compared to other indigenous breeds of Ethiopia (Anteneh et al. 2010; Tesfa et al. 2016). The measurement of BL in this result was accordance with (Khalid 2011) who reported that BL of female Kanana cattle was $87.29 \pm 1.92 \mathrm{~cm}$ as Kanana cattle is dairy cattle in Northern Sudan (Rege 1999). The measurement of WH of dairy cattle had higher value than Sheko cattle $(101.5 \mathrm{~cm})$ and Kanan cattle $(112.67 \pm 1.07$ $\mathrm{cm})$ as reported by Khalid (2011).

There was higher significant variation $(\mathrm{P}<0.0001)$ of wider at the point of shoulder (WAS) in meat type than the rest of cattle types (Figure 4). But there was no significant variation of WAS between dairy type and crossbred cattle. Narrowness WAS (excellent sharpness over the withers) is a common conformation of ideal dairy cattle. Wideness (thick over the withers) of WAS is a common conformation of ideal meat/ beef cattle. As indicated by ICAR (2015), sharpness over the withers leads more (dairyness,

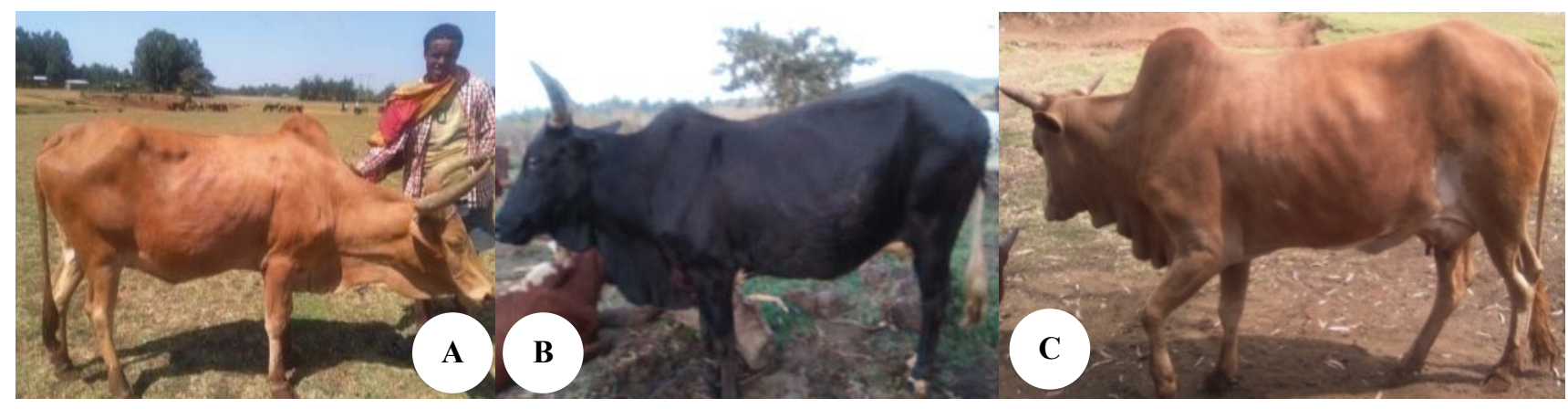

Figure 3. Indigenous dairy type cow at Debecha (A), dual type cow at Finote Selam (B) and meat type cow at Debecha (C)

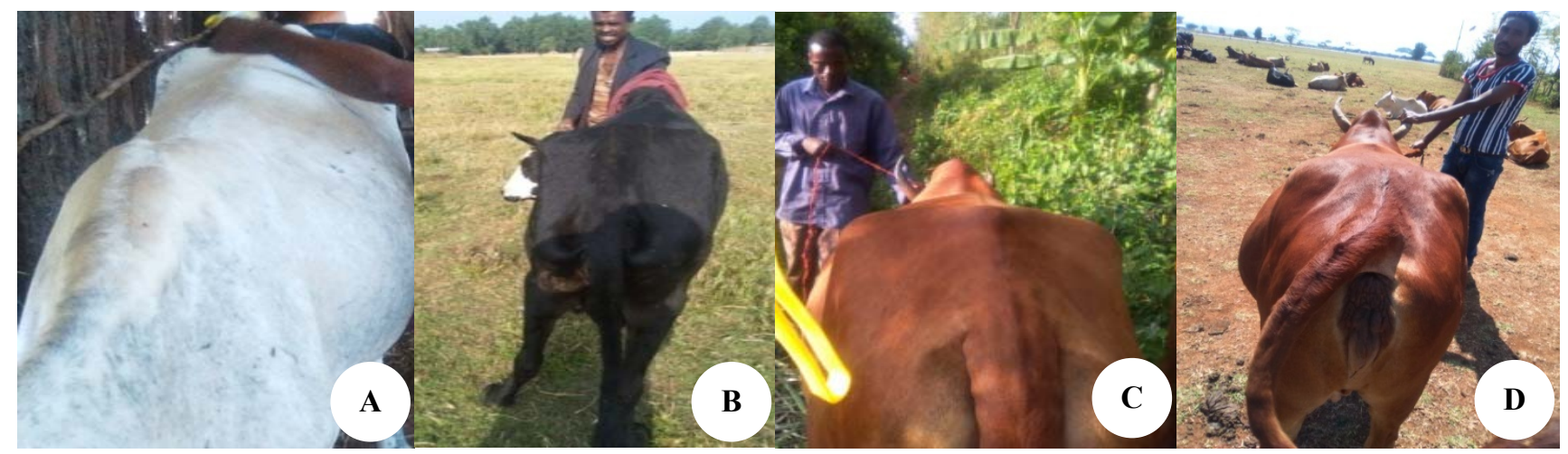

Figure 4. Crossbred (A) and indigenous dairy cattle (B) in Debecha, dual type cattle (C) and meat type cattle (D) in Finote Selam(The arrow shown the sharpness of WAS) 
Table 3. Conformation traits measurement of indigenous cattle populations

\begin{tabular}{|c|c|c|c|c|c|c|c|c|c|c|c|}
\hline \multirow[t]{2}{*}{ Effect and Level } & \multicolumn{2}{|r|}{ ST (cm) } & \multirow{2}{*}{$\begin{array}{c}\text { CW }(\mathrm{cm}) \\
\text { Mean } \pm \text { SD }\end{array}$} & \multirow{2}{*}{$\begin{array}{c}\text { NL (cm) } \\
\text { Mean } \pm \text { SD }\end{array}$} & \multirow{2}{*}{$\begin{array}{l}\text { WAS }(\mathbf{c m}) \\
\text { Mean } \pm \text { SD }\end{array}$} & \multirow{2}{*}{$\begin{array}{c}\text { BD }(\mathrm{cm}) \\
\text { Mean } \pm \text { SD }\end{array}$} & \multirow{2}{*}{$\begin{array}{c}\text { BL (cm) } \\
\text { Mean } \pm \text { SD }\end{array}$} & \multirow{2}{*}{$\begin{array}{c}\text { WH(cm) } \\
\text { Mean } \pm \text { SD }\end{array}$} & \multirow{2}{*}{$\begin{array}{c}\text { HG(cm) } \\
\text { Mean } \pm \text { SD }\end{array}$} & \multirow{2}{*}{$\begin{array}{c}\text { RW }(\mathrm{cm}) \\
M e a n \pm \text { SD }\end{array}$} & \multirow{2}{*}{$\begin{array}{c}\text { RL }(\mathrm{cm}) \\
\text { Mean } \pm \text { SD }\end{array}$} \\
\hline & $\mathbf{N}$ & Mean \pm SD & & & & & & & & & \\
\hline Over all & & $119.17 \pm 5.36$ & $18.68 \pm 2.52$ & $53.24 \pm 4.77$ & $6.40 \pm 1.97$ & $86.65 \pm 7.13$ & $116.56 \pm 8.53$ & $115.94 \pm 8.12$ & $149.61 \pm 13.88$ & $9.76 \pm 1.49$ & $36.62 \pm 2.85$ \\
\hline Cattle type & & $* * *$ & NS & $* *$ & $* * *$ & NS & $* *$ & $* *$ & $* *$ & NS & $* *$ \\
\hline Dairy & 123 & $119.04 \pm 5.44^{\mathrm{B}}$ & $18.35 \pm 2.40^{\mathrm{A}}$ & $54.07 \pm 4.80^{\mathrm{A}}$ & $5.35 \pm 1.61^{\mathrm{C}}$ & $87.46 \pm 6.79^{\mathrm{A}}$ & $115.14 \pm 5.94^{\mathrm{B}}$ & $116.20 \pm 5.28 \mathrm{~B}$ & $146.80 \pm 14.44^{\mathrm{B}}$ & $9.98 \pm 1.41^{\mathrm{A}}$ & $37.00 \pm 2.99^{\mathrm{A}}$ \\
\hline Dual & 111 & $117.33 \pm 5.42^{\mathrm{C}}$ & $18.53 \pm 2.53^{\mathrm{A}}$ & $53.25 \pm 5.06^{\mathrm{AB}}$ & $6.60 \pm 1.68^{\mathrm{B}}$ & $85.95 \pm 7.34^{\mathrm{A}}$ & $115.52 \pm 8.01^{\mathrm{B}}$ & $113.421 \pm 11.16^{\mathrm{C}}$ & $147.57 \pm 14.03^{\mathrm{B}}$ & $9.86 \pm 1.64^{\mathrm{A}}$ & $35.84 \pm 2.60^{\mathrm{B}}$ \\
\hline Meat & 81 & $121.88 \pm 3.92^{\mathrm{A}}$ & $19.37 \pm 2.57^{\mathrm{A}}$ & $51.96 \pm 4.05^{\mathrm{B}}$ & $7.72 \pm 1.96^{\mathrm{A}}$ & $86.37 \pm 7.29^{\mathrm{A}}$ & $120.12 \pm 11.23^{\mathrm{A}}$ & $118.99 \pm 5.15^{\mathrm{A}}$ & $156.68 \pm 9.92^{\mathrm{A}}$ & $9.30 \pm 1.29^{\mathrm{A}}$ & $37.12 \pm 2.76^{\mathrm{A}}$ \\
\hline District & & $* *$ & $* *$ & NS & $*$ & $* *$ & NS & NS & $* *$ & $* * *$ & $* * *$ \\
\hline Finote Selam & 105 & $119.61 \pm 5.76^{\mathrm{A}}$ & $18.67 \pm 2.73^{\mathrm{A}}$ & $52.49 \pm 5.74^{\mathrm{A}}$ & $6.14 \pm 2.17^{\mathrm{B}}$ & $85.83 \pm 7.65^{\mathrm{B}}$ & $116.81 \pm 9.93^{\mathrm{A}}$ & $116.44 \pm 4.69^{\mathrm{A}}$ & $147.51 \pm 19.24^{\mathrm{B}}$ & $10.62 \pm 1.5^{\mathrm{A}}$ & $35.24 \pm 3.35^{\mathrm{B}}$ \\
\hline Debecha & 105 & $120.21 \pm 4.54^{\mathrm{A}}$ & $19.29 \pm 2.45^{\mathrm{A}}$ & $53.37 \pm 4.07^{\mathrm{A}}$ & $6.94 \pm 2.09^{\mathrm{A}}$ & $88.85 \pm 6.93^{\mathrm{A}}$ & $116.58 \pm 8.25^{\mathrm{A}}$ & $116.14 \pm 11.15^{\mathrm{A}}$ & $153.67 \pm 10.68^{\mathrm{A}}$ & $9.19 \pm 1.29^{\mathrm{C}}$ & $37.06 \pm 2.39^{\mathrm{A}}$ \\
\hline Quarit & 105 & $117.60 \pm 5.54^{\mathrm{B}}$ & $17.99 \pm 2.22^{\mathrm{B}}$ & $53.77 \pm 4.50^{\mathrm{A}}$ & $6.03 \pm 1.46^{\mathrm{B}}$ & $84.92 \pm 6.22^{\mathrm{B}}$ & $116.30 \pm 7.48^{\mathrm{A}}$ & $115.27 \pm 6.33^{\mathrm{A}}$ & $146.94 \pm 9.71^{\mathrm{B}}$ & $9.63 \pm 1.25^{\mathrm{B}}$ & $37.37 \pm 2.39^{\mathrm{A}}$ \\
\hline Sex & & $* * *$ & $* *$ & NS & $* * *$ & $* * *$ & $* * *$ & $* * *$ & $* * *$ & $* * *$ & $* * *$ \\
\hline M & 53 & $124.40 \pm 4.92 \mathrm{~A}$ & $19.87 \pm 2.27 \mathrm{~A}$ & $53.96 \pm 4.45 \mathrm{~A}$ & $7.87 \pm 2.23 \mathrm{~A}$ & $93.32 \pm 6.29 \mathrm{~A}$ & $123.64 \pm 6.58^{\mathrm{A}}$ & $121.94 \pm 5.74^{\mathrm{A}}$ & $160.43 \pm 14.18^{\mathrm{A}}$ & $8.89 \pm 1.72^{\mathrm{B}}$ & $39.13 \pm 2.56^{\mathrm{A}}$ \\
\hline $\mathrm{F}$ & 262 & $118.11 \pm 4.81 \mathrm{~B}$ & $18.44 \pm 2.50 \mathrm{~B}$ & $53.09 \pm 4.83 \mathrm{~A}$ & $6.10 \pm 1.77 \mathrm{~B}$ & $85.30 \pm 6.51 \mathrm{~B}$ & $115.12 \pm 8.16^{\mathrm{B}}$ & $114.73 \pm 7.99^{\mathrm{B}}$ & $147.42 \pm 12.77^{\mathrm{B}}$ & $9.94 \pm 1.37^{\mathrm{A}}$ & $36.11 \pm 2.63^{\mathrm{B}}$ \\
\hline
\end{tabular}

Note: $\mathrm{ST}=$ stature, $\mathrm{CW}$ chest width, $\mathrm{NL}=$ neck length, $\mathrm{WAS}=$ width at point of shoulder, $\mathrm{BD}=$ body depth, $\mathrm{BL}=$ body length, $\mathrm{WH}$ weather height, $\mathrm{HG}=$ heart girth, $\mathrm{ANG}=$ angularity, $\mathrm{pt}=$ point given, No.F $=$ number of finger, $\mathrm{RW}=$ rump width, $\mathrm{RL}=$ rump length; $\mathrm{M}=$ male. $\mathrm{F}=$ female. Means with the same letter within the same column are not significant. * Significant at 0.05 level= $\mathrm{p}$ $0.05, * *$ significant at 0.01 level $=\mathrm{p} 0.01$ and $* * *$ significant at 0.001 level $=\mathrm{P} 0.001 ; \mathrm{NS}=$ not significant and $\mathrm{SD}=\mathrm{Standard}$ deviation. 
angularity, milkier appearance), longer and linear neck, less excessive conditions. Refer to Tsuruta (2005), physical characteristics openness of the ribs, sharpness of bones, the thinness of the tail and thigh are all indicators of the cow's ability to make milk. Data from ICAR (2015) noted that cow wideness on WAS lacks in dairy character; utilizes feed to accumulate meat or fat rather than produce milk. The round of beef cattle should be deep and wide, with the widest portion about midway between the tail head and hock. Wide shoulders are the major indicator of muscularity; the wider the shoulders must be a balance, maximum meat on the rump. Comparative measurements of conformation traits can provide evidence of breed relationships and size (Abdulmojeed et al. 2010).

Conformation traits which were significant variation between each cattle type indicated that each cattle type had a distinct feature. A few of conformation traits had no significant variation also indicated that genetic admixture between cattle type; since our breeding system is traditional and natural selection. Alderson (1999), conformation trait assessment is only one factor in selection procedures. Alphonsus et al. (2012) also indicated that the significant effect of sire on the body conformation traits indicates that appropriate breeding plan that will ensure the use of proven sire in the dairy herd combined with good mating system will yield good results.

The overall results of conformation traits measurement of crossbred cattle were a higher significant value $(\mathrm{P}<0.001)$ over indigenous cattle but the lower value $(\mathrm{P}<0.001)$ on WAS. The small body size of indigenous cattle might be the result of natural selection to reduce the sensitivity to fodder shortage in harsher environments, thus its high adaptive capacity to harsher environmental conditions and inbreeding effect. Tesfa et al. (2016) reported that, Fogera cattle breed is declined because of different problems like genetic admixture with uncharacterized local breeds and inbreeding, shift of production system, absence of well-defined breeding programs, poor selection strategy and genetic gain. In the former time there were high cattle population in the area due to large grazing area and availability of feeds as well as enough breeding bulls, but now a day cattle population and breeding bulls are reduced (personal communication).

Conformation traits measurements are essential for selection and identifications of cattle in their types since body conformation traits have high heritability traits. Conformation traits classification is an important tool in decision making as it focuses on the selection of animals that should have a longer herd life, expressing their productive and reproductive potential based on their morphologic traits (Elisandra et al. 2014).

The district had a significant effect $(\mathrm{P}<0.05)$ on ST, $\mathrm{CW}, \mathrm{BD}, \mathrm{HG}, \mathrm{RW}, \mathrm{RL}$ and $\mathrm{NvL}$. But there was no significant effect on NL, BL and $\mathrm{WH}$ in female cattle populations (Table 3 ). The variation was lower in male cattle populations than female in each trait. It might be due to farmers gave higher attention due to management and feeding for his male cattle started from a younger age to replacement oxen and could express its biological development than female.

Sex had a highly significant effect on most of the linear body measurement. As expected conformation traits measurements in males were higher than those in the females except NL (Table 3). Different reports revealed that the mean values of indigenous males are usually greater than their counter female groups (Taye 2005; Garoma 2006).

There was no significant difference of PSW in both effects. The district had a significant effect $(\mathrm{P}<0.001)$ on $\mathrm{SL}$ and $(\mathrm{P}<0.01)$ on $\mathrm{SC}$. Cattle type had no significant effect on SL but was significant effect on $\mathrm{SC}(\mathrm{P}<0.01)$. Dairy type cattle had a higher value than dual, and meat type cattle on SC and can be used as an indicator of a cow is developing good udder circumference born from such a bull.

\section{Dairy type conformation traits}

The overall result of most frequent udder conformations was observed at intermediate levels (4-6 points). The average strong fixed udder was found $3.46 \%$ of the populations. A comparable result was indicated by Aamir et al. (2010), a well strong fixed udder was found in $8.0 \%$ of the samples studied in Sudanese Kenana Cattle.

Over all udder conformations found at intermediate level except low RUH in crossbred cattle and broken CL in meat type cattle. Almost all the udder related traits were laid an intermediate level in all districts.

The overall results of udder conformations were listed in Table (5 and 6) and Figure 5. A high percentage of loose FUA was found in crossbred cattle $(50 \%)$ than dairy type cattle $(1.67 \%)$. Loose and weak FUA was an indicator of poor udder conformation. But indigenous cattle had better (90\% intermediate and $8.33 \%$ extremely strong in dairytype; $100 \%$ intermediate both dual and meat type FUA. Deep UD was found in dairy-type cattle breed (8.33 than crossbred cattle $(4.55 \%)$ meat $(3.33 \%)$ and dual type creed $(2.38 \%)$. A research found by Berry et al. (2004) indicated that there is a strong genetic correlation between UD and FUA (0.92). Cows with shallow udders possessed tighter fore-udder attachments. Mavrogenis et al. (1988) also explained that the heritability of udder circumference and udder depth was moderate to high suggesting that selection should be effective.

A high percent of RUH was laid an intermediate level $>68 \%$ for indigenous cattle and $31.82 \%$ in crossbred cattle. About $63.64 \%$ of crossbred cattle were laid low RUH but not more than $5 \%$ of indigenous cows. A high percent of CL was possessed by dairy cattle which is an indicator of cows with good teat placement. Strong CL was found in dairy-type cow $43.33 \%$ than the rest (dual type $21.43 \%$, meat type $4.17 \%$ and cross cow $0 \%$ ). Selection of cow which had good central ligaments will be possible to improve rear teat placement and teat length indirectly. Milerski et al. (2006) reported that a low correlation was found between udder attachment and central ligament $(\mathrm{r}=$ $0.29)$ on the contrary low negative correlation $(\mathrm{r}=-0.33)$ between central ligament and udder attachment in Tsigai dairy sheep. 
Table 5. Number of cattle (head) according to udder traits description of indigenous female cattle based on judging method (point except TL(cm))

\begin{tabular}{|c|c|c|c|c|}
\hline \multirow{2}{*}{ Phenotypic variance } & \multicolumn{3}{|c|}{ District } & \multirow{2}{*}{ Overall } \\
\hline & Debecha N(\%) & Finote Selam N(\%) & Quarit N(\%) & \\
\hline \multicolumn{5}{|l|}{ Fore udder attachment (FUA) } \\
\hline Weak and loose (1-3) & $0(0)$ & 0 & $1(2.13)$ & $1(0.71)$ \\
\hline Intermediate (4-6) & $29(100)$ & $48(96)$ & $43(91.49)$ & $120(95.83)$ \\
\hline Extremely strong and tight (7-9) & 0 & $2(4)$ & $3(6.38)$ & $5(3.46)$ \\
\hline \multicolumn{5}{|l|}{ Teat length (TL) } \\
\hline Short (2-4) & $13(44.83)$ & $11(22)$ & $17(36.17)$ & $41(34.33)$ \\
\hline Medium (5-7) & 14(48.28) & $32(64)$ & $28(59.57)$ & $74(57.28)$ \\
\hline Long $(8-10)$ & $2(6.89)$ & $7(14)$ & $2(4.26)$ & $11(8.38)$ \\
\hline \multicolumn{5}{|l|}{ Udder Depth (UD) } \\
\hline Deep (1-3) & $2(6.89)$ & $1(2)$ & $2(4.26)$ & $5(4.38)$ \\
\hline Intermediate(4-6) & $25(86.21)$ & $39(78)$ & $44(93.61)$ & $108(85.94)$ \\
\hline Shallow (7-9) & $2(6.89)$ & $10(20)$ & $1(2.13)$ & $13(9.67)$ \\
\hline \multicolumn{5}{|l|}{ Rear Udder Height (RUH) } \\
\hline Low $(1-3)$ & $2(6.90)$ & $2(4)$ & 0 & $4(3.63)$ \\
\hline Intermediate (4-6) & $23(79.31)$ & $41(82)$ & $39(82.98)$ & $103(81.43)$ \\
\hline $\operatorname{High}(7-9)$ & $4(13.79)$ & $8(14)$ & $8(17.02)$ & $20(14.77)$ \\
\hline \multicolumn{5}{|l|}{ Central Ligament (CL) } \\
\hline broken ligament (1-3) & $9(31.03)$ & $8(16)$ & $14(29.79)$ & $31(25.60)$ \\
\hline Intermediate (4-5) & $15(51.72)$ & $22(44)$ & $22(46.81)$ & $59(47.51)$ \\
\hline Deep cleft/strong ligaments (7-9) & $5(17.24)$ & $20(40)$ & $11(23.40)$ & $35(26.88)$ \\
\hline \multicolumn{5}{|l|}{ Rear Teat Placement (RTP) } \\
\hline Outside of quarter $(1-3)$ & $5(17.24)$ & $5(10)$ & $11(23.40)$ & $20(16.88)$ \\
\hline Intermediate (4-6) & $21(72.41)$ & $33(66)$ & $33(70.21)$ & $87(69.55)$ \\
\hline Inside of quarter (7-9) & $3(10.35)$ & $12(24)$ & $3(6.38)$ & $18(13.57)$ \\
\hline \multicolumn{5}{|c|}{ Front teat placement (view from behind) (FTP) } \\
\hline Outside of quarter (1-3) & 0 & $4(8)$ & 0 & $4(2.66)$ \\
\hline Intermediate (4-6) & $27(93.10)$ & $37(74)$ & $35(74.47)$ & $99(80.52)$ \\
\hline Inside of quarter (7-9) & $2(6.90)$ & $9(18)$ & $12(25.53)$ & $23(16.81)$ \\
\hline
\end{tabular}

Note: N: number of observation

Table 6. Number of cattle (head) according to udder traits description based on judging method of FAO (2012) and International Committee for Animal Recording (ICAR, 2015) conducted by researcher

\begin{tabular}{|c|c|c|c|c|c|}
\hline \multirow{2}{*}{ Phenotypic variance } & \multicolumn{4}{|c|}{ Cattle Type } & \multirow{2}{*}{ Overall } \\
\hline & Dairy (\%) & Dual (\%) & Meat (\%) & Cross (\%) & \\
\hline \multicolumn{6}{|l|}{ For udder attachment (FUA) } \\
\hline Weak and loose (1-3) & 1(1.67) & 0 & 0 & $11(50)$ & $12(20.23)$ \\
\hline Intermediate (4-6) & $54(90)$ & $42(100)$ & $24(100)$ & $11(50)$ & $131(85)$ \\
\hline Extremely strong and tight (7-9) & $5(8.33)$ & 0 & 0 & $0(0)$ & $5(2.08)$ \\
\hline \multicolumn{6}{|l|}{ Udder Depth (UD) } \\
\hline Deep $(1-3)$ & $2(8.33)$ & $1(2.38)$ & $2(3.33)$ & $1(4.55)$ & $6(4.65)$ \\
\hline Intermediate(4-6) & $21(87.50)$ & $40(95.24)$ & $47(78.33)$ & $13(59.09)$ & $121(77.79)$ \\
\hline Shallow $(7-9)$ & $1(4.17)$ & $1(2.38)$ & $11(18.67)$ & $8(36.36)$ & $21(15.40)$ \\
\hline \multicolumn{6}{|l|}{ Rear Udder Height (RUH) } \\
\hline Low $(1-3)$ & 1(1.67) & $2(4.76)$ & $1(4.17)$ & $14(63.64)$ & 18(18.49) \\
\hline Intermediate (4-6) & $41(68.33)$ & $35(83.33)$ & $16(66.67)$ & $7(31.82)$ & $110(67.12)$ \\
\hline High (7-9) & $18(30.00)$ & $5(11.90)$ & $7(29.17)$ & $1(4.54)$ & $22(14.45)$ \\
\hline \multicolumn{6}{|l|}{ Central Ligament (CL) } \\
\hline Convex to flat floor (flat), broken ligament (1-3) & $2(3.33)$ & $14(33.33)$ & $15(62.50)$ & $6(27.27)$ & $35(31.61)$ \\
\hline Intermediate (4-5) & $32(53.33)$ & $19(45.24)$ & $8(33.33)$ & $16(72.73)$ & $75(51.16)$ \\
\hline Deep cleft/strong ligaments (7-9) & $26(43.33)$ & $9(21.43)$ & $1(4.17)$ & $0(0)$ & $36(17.23)$ \\
\hline \multicolumn{6}{|l|}{ Rear Teat Placement (RTP) } \\
\hline Outside of quarter (1-3) & $5(8.33)$ & $16(38.10)$ & 0 & $2(9.09)$ & $23(13.88)$ \\
\hline Intermediate (4-6) & $44(73.33)$ & $19(45.24)$ & $24(100)$ & $17(77.27)$ & $104(73.96)$ \\
\hline Inside of quarter (7-9) & $11(18.33)$ & $7(16.66)$ & 0 & $3(13.64)$ & $21(12.16)$ \\
\hline \multicolumn{6}{|l|}{ Front teat placement (view from behind) (FTP) } \\
\hline Outside of quarter (1-3) & $2(3.33)$ & $1(2.38)$ & $1(4.16)$ & $3(13.64)$ & $7(5.88)$ \\
\hline Intermediate (4-6) & $48(80.00)$ & $32(76.19)$ & $19(79.17)$ & $17(77.27)$ & $116(78.29)$ \\
\hline Inside of quarter (7-9) & $10(16.67)$ & $9(21.43)$ & $4(16.67)$ & $2(9.09)$ & $25(15.90)$ \\
\hline
\end{tabular}




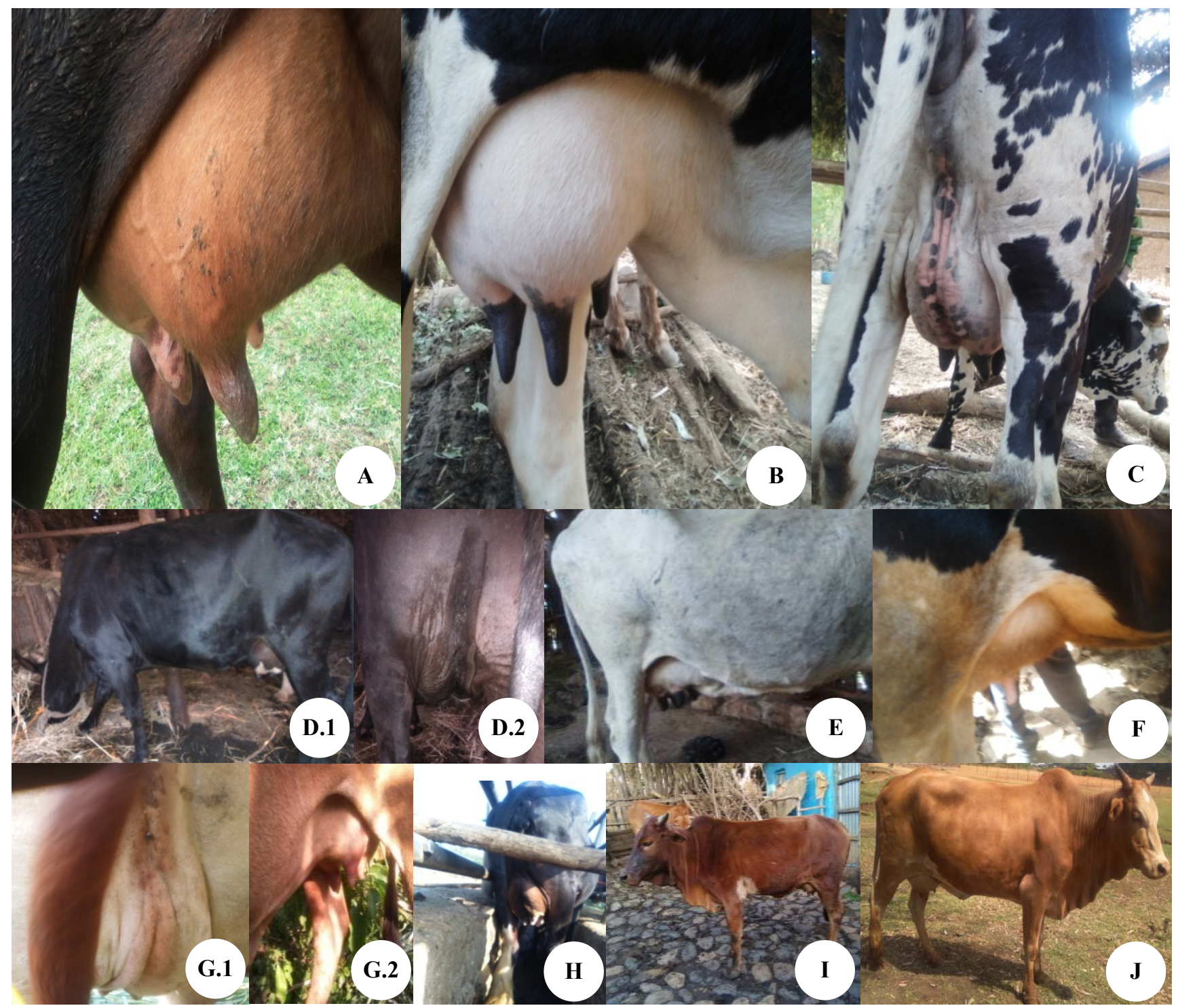

Figure 5. Indigenous and cross cows udder conformation. Note: (i) Dairy types cows (A, B, C) at Debecha, (ii) Cross cows (D, E, F) at Finote Selam, (iii) Dual type cows (G, H) at Finote Selam and Quarit, (iv) Meat typecows (I, J) at Quarit and Debecha

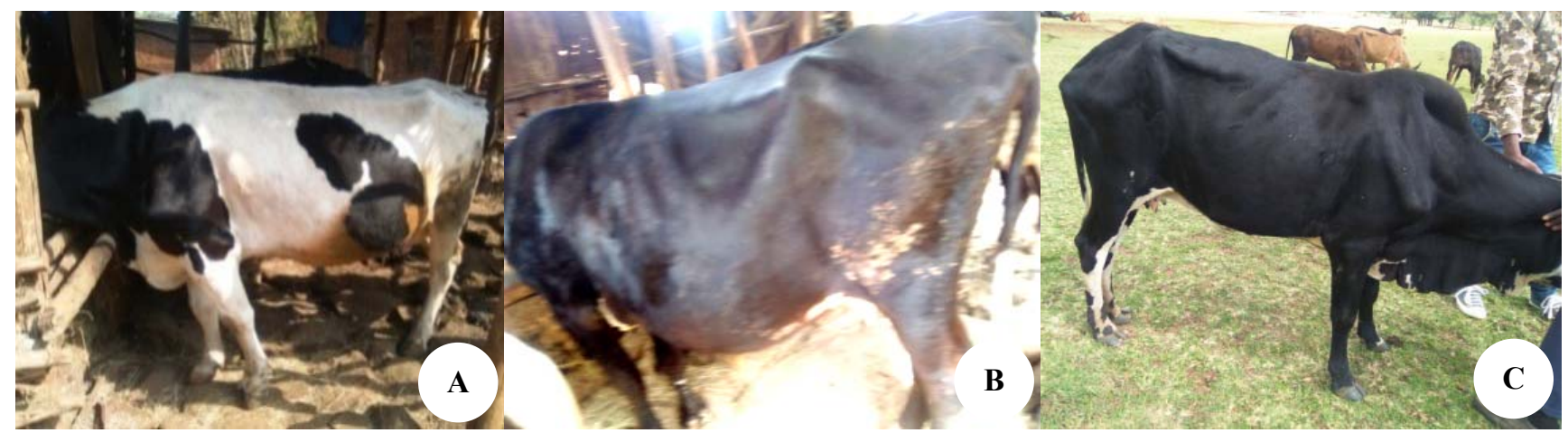

Figure 6. Sickle leg and high pin cross cow (A, B), and normal leg and rump position indigenous cow (C) 
Table 7. Number of cattle (head) according to leg, angularity and rump structure traits based on judging method of FAO (2012) and International Committee for Animal Recording (ICAR 2015) conducted by researcher

\begin{tabular}{|c|c|c|c|c|c|c|c|}
\hline \multirow[t]{2}{*}{ Parameter } & \multicolumn{4}{|c|}{ Cattle type } & \multicolumn{3}{|c|}{ District } \\
\hline & Dairy & Dual & Meat & Cross & Debecha & Quarit & Finote Selam \\
\hline \multicolumn{8}{|l|}{ Angularity } \\
\hline Point given & $\mathrm{N}(\%)$ & $\mathrm{N}(\%)$ & N (\%) & $\mathrm{N}(\%)$ & N (\%) & $\mathrm{N}(\%)$ & $\mathrm{N}(\%)$ \\
\hline Lacks angularity: close ribs, coarse bone (1-3) & 0 & $20(20.2)$ & $43(75.4)$ & $1(2.4)$ & $22(20.8)$ & $19(19.2)$ & $26(31.7)$ \\
\hline Intermediate: with open rib (4-6) & $45(42.5)$ & $75(75.8)$ & $14(24.6)$ & $1(2.4)$ & $49(46.2)$ & $66(66.7)$ & $29(35.4)$ \\
\hline Very angular: open ribbed flat bone (7-9) & $61(57.5)$ & $4(4.0)$ & 0 & $40(95.2)$ & $35(33.0)$ & $14(14.1)$ & $27(32.9)$ \\
\hline \multicolumn{8}{|l|}{ Number of fingers } \\
\hline narrow $1-3=1-1.5$ & $7(6.6)$ & $9(9.1)$ & $13(22.8)$ & $6(14.3)$ & 19(17.9) & $3(3.0)$ & $8(9.8)$ \\
\hline intermediate $4-6=2-2.5$ & $58(54.7)$ & $66(66.7)$ & $31(54.4)$ & $22(52.4)$ & $69(65.1)$ & $52(52.5)$ & $50(61.0)$ \\
\hline wide $7-8=3-3.5$ & $41(38.7)$ & $24(24.2)$ & $13(22.8)$ & $13.2(33.3$ & $18(17.0)$ & $44(44.4)$ & $24(29.3)$ \\
\hline \multicolumn{8}{|l|}{ Rump angle } \\
\hline High Pins (1-3) & $1(.9)$ & 0 & 0 & $3(7.1)$ & 0 & $1(1.0)$ & 0 \\
\hline Intermediate(4-6) & $95(89.6)$ & $95(96.0)$ & $55(96.5)$ & $34(81.0)$ & $101(95.3$ & $91(91.9)$ & $75(91.5)$ \\
\hline Extreme slope(7-9) & $10(9.4)$ & $4(4.0)$ & $2(3.5)$ & $5(11.9)$ & $5(4.7)$ & $7(7.1)$ & $7(8.5)$ \\
\hline \multicolumn{8}{|l|}{ Rear leg seats } \\
\hline Straight (1-3) & $1(.9)$ & 0 & 0 & 0 & 0 & $1(1.0)$ & 0 \\
\hline Intermediate(4-6) & $97(91.5)$ & 93(93.9) & $57(100.0$ & $18(42.9)$ & $103(97.2$ & $88(88.9)$ & $80(97.6)$ \\
\hline Sickled (7-9) & $8(7.5)$ & $6(6.1)$ & 0 & $24(57.1)$ & $3(2.8)$ & $10(10.1)$ & $2(2.4)$ \\
\hline \multicolumn{8}{|l|}{ Naval flap length } \\
\hline Absent $(0-0.5)$ & $6(5.7)$ & $4(4.0)$ & $1(1.8)$ & $28(66.7)$ & $7(6.6)$ & $1(1.0)$ & $6(7.3)$ \\
\hline Small (1-4.5) & $75(70.8)$ & $69(69.7)$ & $43(75.4)$ & $10(23.8)$ & $78(73.6)$ & $74(74.7)$ & $45(54.9)$ \\
\hline Medium (5-8) & $21(19.8)$ & $19(19.2)$ & $13(22.8)$ & $3(7.1)$ & $17(16.0)$ & $22(22.2)$ & $22(26.8)$ \\
\hline Large $(9-13)$ & $4(3.8)$ & $7(7.1)$ & () & $1(2.4)$ & $4(3.8)$ & $2(2.0)$ & $9(11.0)$ \\
\hline
\end{tabular}

Note: Angularity (ANG), Rump angle (RA), Rear leg sets (RLS)

The overall results of angularity about $57.5 \%$ very angular in dairy type, about $75 \%$ intermediate in dual type, about $75.4 \%$ lack angularity in meat type and about $95.2 \%$ very angular in crossbred cattle (Table 6,7 and Figure 3). In respect to RLS about $91.5 \%, 93.9 \%$, and $100 \%$ were laid at the intermediate level dairy, dual and meat type cattle, respectively (Table 7). But $57.1 \%$ of crossbred was sickle legs (Figure 4.A and B).Farmers stated that, sickle legs were difficult to walk in long distance in fragile land for forage and to perform draught work, especially in rural community. Similarly to the current findings, Zavadilová et al. (2009) reported that, feet and legs are potential indicators of a cow's longevity. Crossbred cattle had short longevity and not persist suitable for rural community work for trashing, plowing and discover long distance for forage and water in the field. Wiggans et al. (2010) reported that, RLS were importance for locomotion and longevity. Bad leg conformation strongly affects animal welfare, and feet defects lead to diseases and lameness. Similarly Gordon et al. (2008), locomotion is a qualitative observation of a cow's ability to walk normally to identify functionality Canadian Holstein.

All conformation traits were found at the intermediate point in all districts even if the percentage varied. So district had no such big effect on the above qualitative traits.

In conclusion, this research investigated the existence of three main cattle types: dairy, dual and meat types based on the conformational characterization of indigenous cattle. Most of the conformation traits were significantly different $(\mathrm{p}<0.01)$ especially NL, WH, WAS and BL among cattle types. Most of the udder conformation traits were found an intermediate level of in dairy-type cattle but low RUH and broken CL in a crossbred cow. Over $50 \%$ of RLS was sickle in crossbred cattle but intermediate in dairy-type cattle. Dairy type cattle had distinct traits from the rest of indigenous cattle. The conformational traits data obtained in this study are vital and valuable in management and useful tool in future strategies and should be well utilized to improve the performance of indigenous dairy and meet type cattle. Hence, establish adequate selection, and breeding plan can help to exploit their traits for the future dairy cattle genetic improvements. However, farmers did not select cattle for a specific purpose rather keep for multipurpose.

\section{ACKNOWLEDGEMENTS}

The authors would like to acknowledge the cattle owners in the study for their cooperation during data collection. We would like also thank Debre-Markos University, Ethiopia for funding this research.

\section{REFERENCES}

Aamir HM, Babiker SA, Youssif GM, HassanYA. 2010. Phenotypic Characterization of Sudanese Kenana Cattle. Res J Anim Vet Sci 5: 43-47.

Abdulmojeed Y, Kingsley O, Hadiza S, Matthew W, Samuel A.2010. Multivariate analysis of phenotypic differentiation in Bunaji and Sokoto Gudali cattle. Acta Agriculturae Slovenica 96 (2): 75-80. 
Alderson GLH. 1999. The development of a system of linear measurements to provide an assessment of type and function of beef cattle. J Anim Genet Res 25: 45-55.

Alphonsus C, Akpa GN, Kpanja EJ, Finangwai I H, Byanet O.2012. Genetic and Non Genetic Sources of Variation for Linear body Conformation Traits in Bunaji and Friesian $\mathrm{X}$ Bunaji cow. Agrosearch 12 (1): 51-60.

Anteneh B, Tegene A, Beyene F, Gebremedhin B. 2010. Cattle milk and meat production and marketing systems and opportunities for marketorientation in Fogera Woreda, Amhara region, Ethiopia. ILRI, Nairobi, Kenya. Working Paper No. 19.

Bahashwan S. 2014. Dhofari cattle growth curve prediction by differen non-linear model functions. Salalah Livestock Research Station, Ministry of Agriculture and Fisheries, Oman.

Berry DP, Buckley F, Dillon P, Evans RD, Veerkamp RF. 2004. Genetic relationship among linear type traits, milk yield, body weight, fertility and somatic cell count in primiparous dairy cows. Irish J Agric Food Res 43 (2): 161-176

CSA (Central Statistical Agency of Ethiopia). 2015/2016. National census conducted by the Central Statistical Agency of Ethiopia.

District Agricultural Offices. 2015. West Gojjam, Amhara, Ethiopia

Elisandra LK, Jaime AC, Cláudio NC ,Concepta MM.2014. Factor Analysis of Linear Type Traits and Their Relation with Longevity in Brazilian Holstein Cattle. Asian-Austr J Anim Sci 6: 784-790.

FAO. 2012. The State of Food and Agriculture; Livestock in the Balance. Food and Agriculture Organization of the United Nations, Rome, Italy.

Ftiwi M. 2015. Production system and phenotypic characterization of begait cattle and effects of supplementation with concentrate feeds on milk yield and composition of begait cows in humera ranch, western tigray, Ethiopia. [Dissertation]. Addis Ababa University, Addis Ababa, Ethiopia.

Garoma S. 2006. In-situ Phenotypic Characterization of Kereyu cattle type in Fentale district of Oromia Region, Ethiopia [Thesis]. School of Graduate Studies, Haramaya University, Ethiopia.

Gordon PM, Soliman MA, Bose P, Trinh Q, Sensen CW, Riabowol K 2008. Interspecies data mining to predict novel ING-protein interactions in human. BMC Genomics 9: 426. DOI: 10.1186/14712164-9-426.

Hannotte O, Jianlin H. 2005. Genetic characterization of livestock populationss and its use in conservation decision making. The role of biotechnology in exploring and protecting genetic resources. the role of biotechnology,Villa Gualino, Turin, Italy-5-7 March, 2005, Rome.

ICAR. 2015. Selecting and judging dairy heifers, Conformation Working Group. International Committee for Animal Recording, Rome, Italy.
Khalid M. 2011. Morphometric traits as indicators for body weight in Sudanese Kenana Cattle. University of Khartoum, Sudan.

Mavrogenis AP, Papachristoforou C, Lysandrides P, Roushias A. 1988. Environmental and genetic factors affecting udder characters and milk production in Chios sheep. Genetique Selection Evolution 20 (4): 477-488.

Milerski M, Margetín M, Čapistrák A, Apolen D, Špánik J, Oravcová M. 2006. Relationships between external and internal udder measurements and the linear scores for udder morphology traits in dairy sheep. Czech J Anim Sci 51 (9): 383-390.

Mwacharo JM, Okeyo A M, Kamande GK. and Rege JEO.2006. The small East Africa shorthorn zebu cows in Kenya. Trop Anim Health Product 38: 65-74.

Pace JE, Wakeman DL. 2003. Determining the age of cattle by their teeth. CIR253. Florida Cooperative Extension Service, Institute of Food and Agricultural Sciences. University of Florida, Gainesville.

Rege JEO. 1999. The state of African cattle genetic resources I. Classification framework and identification of threatened and extinct breeds. International Livestock Research Institute (ILRI), Addis Ababa, Ethiopia.

SAS. 2014. Statistical Analysis System, "Software version 9.1" SAS Institute Inc., Cary, NC, USA, 2014.

SPSS. 2007. (Statistical Package for Social Science), Release 17.0, The Apasche software foundation.

Tadesse S, Fesaha G, Abebe A, Hailu B, Dejen W. 2014. Assessment of productive and reproductive performances of cross breed dairy cows in Debre Tabor town. J Biol Agric Healthcare 4 (23): 112-115.

Taye T.2005. On-farm phenotypic characterization of Sheko breed of cattle and their habitat in Bench Maji Zone, Ethiopia.; MSc Thesis, Alemaya University, Ethiopia.

Tesfa A, Kumar D, Abegaz S, Mekuriaw G. 2016. Evaluations of reproductive performances of fogera cattle breed in selected Districts of Amhara Region, Ethiopia. Intl J Pharma Med Biol Sci 5 (1): 52-57.

Tsuruta S.2005. New application of conformation trait data for dairy cow improvement; University of Georgia, Athens.

Veerkamp RF, Gerritsen CLM, Koenen EPC. 2002. Evaluation of classifiers that score linear type traits and body condition score using common sires. J Dairy Sci 85 (4): 976-983.

Wiggans GR, Van Raden PM, Bacheller LR, Tooker ME, Hutchison JL, Cooper TA, Sonstegard TS. 2010. Selection and management of DNA markers for use in genomic evaluation. J Dairy Sci 93: 22872292

Zavadilová L, Němcová E, Štípková M, Bouška J. 2009. Relationships between longevity and conformation traits in Czech Fleckvieh cows. Czech J Anim Sci 54: 387-394. 